\title{
Assessment of Continuous Oil and Gas Resources in the Duvernay Formation, Alberta Basin Province, Canada, 2018
}

Using a geology-based assessment methodology, the U.S. Geological Survey estimated undiscovered, technically recoverable mean resources of 1.3 billion barrels of oil and 22.2 trillion cubic feet of gas in the Duvernay Formation of the Alberta Basin Province, Canada.

\section{Introduction}

The U.S. Geological Survey (USGS) quantitatively assessed the potential for undiscovered, technically recoverable continuous (unconventional) oil and gas resources in the Late Devonian Duvernay Formation of the Alberta Basin Province in Canada (fig. 1). The Duvernay Formation represents transgressive basinal shales deposited in oxygen-deficient, relatively shallow (100 meters or less) water adjacent to similar-age carbonate platform and fringing reefs of the Leduc Formation (Dunn and Humenjuk, 2014; Fothergill and others, 2014). In the Late Devonian, carbonate platforms and adjacent basins were located along the passive western margin of North America with open-marine conditions to the west. From the Carboniferous through the Triassic, subduction and collision of several terranes along the western margin of North America resulted in a long period of uplift, erosion, or nondeposition. The formation of an east-verging fold and thrust belt and foreland basin in the Late Jurassic and its continued development into the Late Cretaceous through Paleogene provided the necessary burial for adequate thermal maturity for oil and gas generation (Fowler and others, 2001). Since the Eocene, the basin has uplifted and eroded.

\section{Total Petroleum System and Assessment Units}

The USGS defined a Duvernay Total Petroleum System (TPS) and assessed potential continuous oil and gas resources within this TPS. The Duvernay Formation consists of dark, bituminous, organic-rich lime mudstones that form an important petroleum source rock for conventional oil and gas accumulations (Switzer and others, 1994). Shales of the Duvernay Formation contain Type II organic matter, have organic carbon contents of as much as 20 weight percent, have hydrogen index values of as much as 600 milligrams of hydrocarbon per gram of organic carbon, are overpressured (up to 0.84 pounds per square inch per foot), and can be as much as 70 meters thick (Fowler and others, 2001; Chen and Jiang, 2016; Davis and others, 2016). Duvernay Formation oils are generally low in sulfur (less than 0.5 percent), but gas from the Duvernay Formation can contain several percent of hydrogen sulfide (Van de Wetering and others, 2015). Thermal maturity maps show that shales in the eastern part of the basin are thermally immature, but shales in the western part are thermally mature for oil and gas generation (Stoakes and Creaney, 1984). Burial in the foreland basin during the Late Cretaceous through Paleogene was sufficient to have thermally matured organic matter in these shales (Fowler and others, 2001; Machel and others, 2012).

The geologic model for the Duvernay TPS is for oil and gas to have been generated from Late Devonian source rocks primarily because of Late Cretaceous-Paleogene foredeep burial. Oil and gas were partially retained within the Duvernay Formation shales following generation and migration of oil and gas into conventional carbonate traps. For this study, the Duvernay Shale Oil Assessment Unit (AU) and North Duvernay Shale Oil AU were defined to encompass areas of shale within the oil-generation window, and the Duvernay Shale Gas AU was defined to include the area potentially within the gas-generation window. Uncertainty in the

assessment is related to the thermal maturity boundaries as mapped and to the retention of oil and gas within Duvernay Formation shales.

Assessment input data are summarized in table 1. Input data for drainage areas, success ratios, and estimated ultimate recoveries are guided by geologic analogs in the United States.

\section{Undiscovered Resources Summary}

The USGS quantitatively assessed continuous oil and gas resources in three assessment units (table 2) in the Duvernay Formation of the Alberta Basin Province, Canada. For undiscovered, technically recoverable continuous oil and gas resources, the estimated mean cumulative resources are 1,347 million barrels of oil (MMBO), or 1.3 billion barrels of oil, with an F95-F5 fractile range from 303 to 2,946 MMBO; 22,238 billion cubic feet of gas (BCFG), or 22.2 trillion cubic feet of gas (TCFG), with an F95-F5 fractile range from 5,196 to 47,154 BCFG; and 874 million barrels of natural gas liquids (MMBNGL) with an F95-F5 fractile range from 190 to 1,947 MMBNGL.

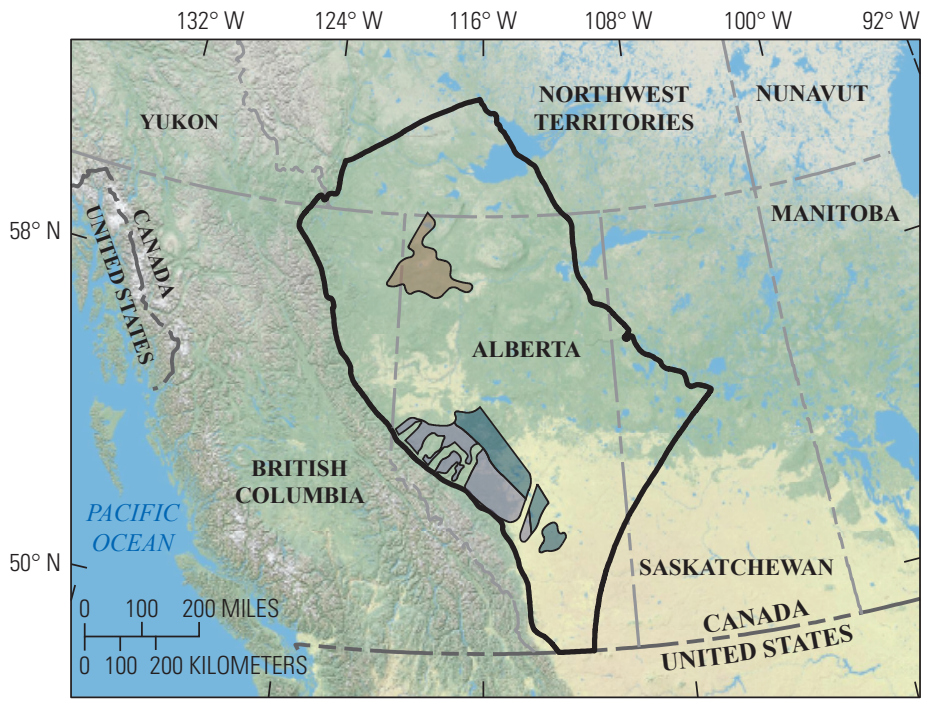

Base map from U.S. Department of the Interior National Park Service

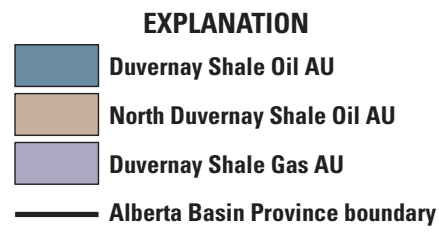

Figure 1. Map showing the three continuous assessment units (AUs) in the Duvernay Formation of the Alberta Basin Province, Canada. Province boundary is from Klett and others, 1997.

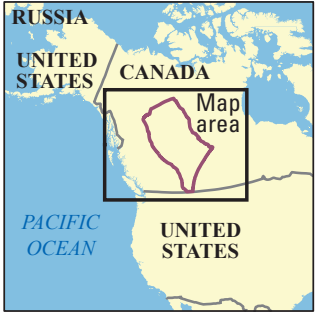

Alberta Basin Province boundary is shown in plum. 
Table 1. Key input data for three continuous assessment units (AUs) in the Duvernay Formation of the Alberta Basin Province, Canada.

[AU, assessment unit; \%, percent; EUR, estimated ultimate recovery per well; MMBO, million barrels of oil; BCFG, billion cubic feet of gas; Well drainage area, success ratio, and EUR are defined partly using U.S. shale-oil and shale-gas analogs. The average EUR input is the minimum, median, maximum, and calculated mean. Shading indicates not applicable]

\begin{tabular}{|c|c|c|c|c|c|c|c|c|}
\hline \multirow[b]{2}{*}{ Assessment input data-Continuous AUs } & \multicolumn{4}{|c|}{ Duvernay Shale Oil AU } & \multicolumn{4}{|c|}{ North Duvernay Shale Oil AU } \\
\hline & Minimum & Mode & Maximum & $\begin{array}{l}\text { Calculated } \\
\text { mean }\end{array}$ & Minimum & Mode & Maximum & $\begin{array}{l}\text { Calculated } \\
\text { mean }\end{array}$ \\
\hline Potential production area of AU (acres) & 1,000 & $3,230,000$ & $6,460,000$ & $3,230,333$ & 1,000 & $2,634,500$ & $5,269,000$ & $2,634,833$ \\
\hline Average drainage area of wells (acres) & 120 & 180 & 240 & 180 & 120 & 180 & 240 & 180 \\
\hline Success ratio $(\%)$ & 10 & 70 & 90 & 56.7 & 10 & 50 & 90 & 50 \\
\hline Average EUR (MMBO) & 0.03 & 0.08 & 0.2 & 0.086 & 0.02 & 0.06 & 0.15 & 0.064 \\
\hline AU probability & 1.0 & & & & 1.0 & & & \\
\hline \multirow[b]{2}{*}{ Assessment input data—Continuous AU } & \multicolumn{4}{|c|}{ Duvernay Shale Gas AU } & & & & \\
\hline & Minimum & Mode & Maximum & $\begin{array}{c}\text { Calculated } \\
\text { mean }\end{array}$ & & & & \\
\hline Potential production area of AU (acres) & 1,000 & $4,185,000$ & $8,214,000$ & $4,133,333$ & & & & \\
\hline Average drainage area of wells (acres) & 80 & 120 & 160 & 120 & & & & \\
\hline Success ratio $(\%)$ & 10 & 70 & 90 & 56.7 & & & & \\
\hline Average EUR (BCFG) & 0.1 & 1 & 2 & 1.036 & & & & \\
\hline AU probability & 1.0 & & & & & & & \\
\hline
\end{tabular}

Table 2. Results for three continuous assessment units (AUs) in the Duvernay Formation of the Alberta Basin Province, Canada.

[MMBO, million barrels of oil; BCFG, billion cubic feet of gas; NGL, natural gas liquids; MMBNGL, million barrels of natural gas liquids. Results shown are fully risked estimates. F95 represents a 95-percent chance of at least the amount tabulated; other fractiles are defined similarly. Fractiles are additive under the assumption of perfect positive correlation. Shading indicates not applicable]

\begin{tabular}{|c|c|c|c|c|c|c|c|c|c|c|c|c|c|c|}
\hline \multirow{3}{*}{$\begin{array}{l}\text { Total petroleum system } \\
\text { and assessment units (AUs) }\end{array}$} & \multirow{3}{*}{$\underset{\text { probability }}{\text { AU }}$} & \multirow{3}{*}{$\begin{array}{c}\text { Accumulation } \\
\text { type }\end{array}$} & \multicolumn{12}{|c|}{ Total undiscovered resources } \\
\hline & & & \multicolumn{4}{|c|}{ Oil (MМBO) } & \multicolumn{4}{|c|}{ Gas (BCFG) } & \multicolumn{4}{|c|}{ NGL (MMBNGL) } \\
\hline & & & F95 & F50 & F5 & Mean & F95 & F50 & F5 & Mean & F95 & F50 & F5 & Mean \\
\hline \multicolumn{15}{|c|}{ Duvernay Total Petroleum System } \\
\hline Duvernay Shale Oil AU & 1.0 & Oil & 198 & 776 & 1,901 & 876 & 289 & 1,149 & 2,903 & 1,313 & 11 & 45 & 121 & 52 \\
\hline North Duvernay Shale Oil AU & 1.0 & Oil & 105 & 409 & 1,045 & 471 & 152 & 607 & 1,590 & 706 & 3 & 12 & 33 & 14 \\
\hline Duvernay Shale Gas AU & 1.0 & Gas & & & & & 4,755 & 18,254 & 42,661 & 20,219 & 176 & 707 & 1,793 & 808 \\
\hline Total undiscovered continuous resources & & & 303 & 1,185 & 2,946 & 1,347 & 5,196 & 20,010 & 47,154 & 22,238 & 190 & 764 & 1,947 & 874 \\
\hline
\end{tabular}

\section{References Cited}

Chen, Z., and Jiang, C., 2016, A revised method for organic porosity estimation in shale reservoirs using Rock-Eval data-Example from Duvernay Formation in the Western Canada Sedimentary Basin: American Association of Petroleum Geologists Bulletin, v. 100, no. 3, p. 405-422.

Davis, M., Karlen, G., Tobey, M., and Tivey, D., 2016, Insights into the evolution of an intracratonic foreland basin-A regional assessment of the Duvernay Formation, chap. 4 of Dolan, M.P., Higley, D.K., and Lillis, P.G., eds., Hydrocarbon source rocks in unconventional plays, Rocky Mountain region: The Rocky Mountain Association of Geologists, p. 137-171.

Dunn, L.A., and Humenjuk, J., 2014, The Duvernay Formation-Integrating sedimentology, sequence stratigraphy and geophysics to identify sweet spots in a liquids-rich shale play, Kaybob Alberta, in Unconventional Resources Technology Conference, Denver, Colo., August 25-27, 2014, Proceedings: Society of Exploration Geophysicists, American Association of Petroleum Geologists, Society of Petroleum Engineers, URTeC 19-22713-MS, 7 p., accessed June 26, 2018, at https://www.onepetro.org/conference-paper/URTEC-1922713-MS.

Fothergill, P., Boskovic, D., Schoellkopf, N., Murphy, P., and Mukati, M.A., 2014 Regional modelling of the Late Devonian Duvernay Formation, Western Alberta, Canada, in Unconventional Resources Technology Conference, Denver, Colo., August 25-27, 2014, Proceedings: Society of Exploration Geophysicists, American Association of Petroleum Geologists, Society of Petroleum Engineers, URTeC 1923935-MS, 8 p., accessed June 26, 2018, at https://www.onepetro.org/ conference-paper/URTEC-1923935-MS.
Fowler, M.G., Stasiuk, L.D., Hearn, M., and Obermajer, M., 2001, Devonian hydrocarbon source rocks and their derived oils in the Western Canada Sedimentary Basin: Bulletin of Canadian Petroleum Geology, v. 49, no. 1, p. 117-148.

Klett, T.R., Ahlbrandt, T.S., Schmoker, J.W., and Dolton, G.L., 1997, Ranking of the world's oil and gas provinces by known petroleum volumes: U.S. Geological Survey Open-File Report 97-463, 1 CD-ROM. [Also available at https://pubs.usgs.gov/ of/1997/ofr-97-463/97463.html.]

Machel, H.G., Borrero, M.L., Dembicki, E., Huebscher, H., Ping, L., and Zhao, Y., 2012, The Grosmont-The world's largest unconventional oil reservoir hosted in carbonate rocks, in Garland, J., Neilson, J.E., Laubach, S.E., and Whidden, K.J., eds., Advances in carbonate exploration and reservoir analysis: The Geological Society of London, Special Publication No. 370, p. 49-81.

Stoakes, F.A., and Creaney, S., 1984, Sedimentology of a carbonate source rock-The Duvernay Formation of Central Alberta, in Uliak, L., ed., Carbonates in subsurface and outcrop-Proceedings of the 1984 C.S.P.G. Core Conference, Calgary, Alberta, Canada, October 18-19, 1984: Canadian Society of Petroleum Geologists (C.S.P.G.), p. 132-147.

Van de Wetering, A., Mayer, B., and Sanei, H., 2015, Chemostratigraphic associations between trace elements and organic parameters within the Duvernay Formation, Western Canada Sedimentary Basin, in Unconventional Resources Technology Conference, San Antonio, Tex., July 20-22, 2015, Proceedings: Society of Exploration Geophysicists, American Association of Petroleum Geologists, Society of Petroleum Engineers, URTeC 2153955, 11 p., accessed June 26, 2018, at http://archives.datapages.com/data/urtec/2015/2153955.pdf.

\section{For More Information}

Assessment results are also available at the USGS Energy Resources Program website at https://energy.usgs.gov.

\section{Duvernay Formation Assessment Team}

Christopher J. Schenk, Tracey J. Mercier, Marilyn E. Tennyson, Phuong A. Le, Michael E. Brownfield, Kristen R. Marra, Stephanie B. Gaswirth, Heidi M. Leathers-Miller, and Ronald M. Drake II 